Bartosz Płotka

Uniwersytet Mikołaja Kopernika

L. Balcerowicz, Odkrywając wolność. Przeciw zniewoleniu umysłów, Wydawnictwo Zysk i S-ka, Warszawa 2012, ss. 1042.

\title{
Balcerowicza remedium w sprawie liberi fatali współczesności
}

Recepcja pojęcia wolności ulegała diametralnym przeobrażeniom na przestrzeni wieków. Zmiany te doprowadziły do wyodrębnienia przynajmniej kilku głównych nurtów myślowych w refleksji nad wolnością, także w ramach poszczególnych dziedzin nauki. Bycie wolnym ma inne znaczenie dla fizyka i artysty, neurobiologa i politologa, prawnika i socjologa, etc. By dopełnić tego obrazu należy pamiętać o tym, że rozumienie tytułowego zagadnienia może pozostawać odmienne również w obrębie tej samej dyscypliny. Wyszczególnia się zatem pluralizm wolności, który w swojej wewnętrznej dialektyce prowadzi do rozmazania pojęcia. Kiedy granice wolności tracą ostrość, rozpoczyna się pierwszy akt dramatu: wolność przeobraża się w dowolność, która ujarzmia swoją poprzednią postać, odbiera jej cnotę i kradnie tożsamość, wyzwala jej negatywne oblicze i triumfalnie paraduje w płaszczu swojej intuicyjnej interpretacji. Efektem występnego zabiegu dowolności jest zniewolenie człowieka w akcie jego samowoli. Samowolą zaś zachłystuje się społeczeństwo - ulegają kontaminacji jego porządek i umowa. Zupełnie inne, choć oparte na tych samych obawach, podejście do interdyscyplinarnego charakteru pojęcia wolności proponuje Leszek Balcerowicz w publikacji zatytułowanej Odkrywając wolność. Przeciw zniewoleniu umysłów.

Leszek Balcerowicz jest profesorem ekonomii w Szkole Głównej Handlowej w Warszawie. Uzyskał także tytuł MBA w St. John’s University w Nowym Jorku. Za osiągnięcia naukowe został uhonorowany tytułem doctora honoris causa na ponad 20 uniwersytetach całego świata. Swoimi umiejętnościami ekonomicznymi wsparł transformację ustrojową Polski w latach 1989-2007, w czasie których pełnił funkcję 
ministra finansów oraz prezesa Narodowego Banku Polskiego. Obecnie przewodniczy Fundacji Forum Obywatelskiego Rozwoju. Do jego najważniejszych prac zalicza się: Wolność i rozwój. Ekonomia wolnego rynku (1995), Socjalizm. Kapitalizm. Transformacja. Szkice z przełomu epok (1997), Państwo w przebudowie (1999).

Struktura publikacji Odkrywając wolność. Przeciw zniewoleniu umysłów odpowiada liczbie głównych nurtów rozważań nad wolnością w jej społecznym ujęciu. Tak więc wyodrębniono pięć rozdziałów poświęconych kolejno: naturze ludzkiej jako podstawie kontraktu społecznego, pojęciom państwa i demokracji, pojęciom własności i rynku, pojęciom jednostki i wspólnoty oraz konfliktowi liberalizmu z antyliberalizmem. Trzeba tutaj nadmienić, że Balcerowicz dokonał jedynie wyboru, uznanych przez siebie za najważniejsze, tekstów reprezentujących te zagadnienia. Swoje poglądy przedstawił natomiast w obszernym wstępie do recenzowanego tomu.

Ekonomista zauważa, że zagrożenie swobód demokratycznych na gruncie społecznym wynika z jałowości dyskusji publicznych oraz nieprecyzyjnego rozumienia pojęć, którymi posługują się ich uczestnicy. Pisze: „ten zamęt dezorganizuje myślenie, a przez to - działanie"1 i wychodzi tym problemom naprzeciw. Przekonuje, że liberalizm i myśl społeczno-gospodarcza szukają swych korzeni w wolności. Dlatego też proponuje czytelnikowi m.in. znamienity esej Davida Hume’a $O$ wolności i konieczności, klasyczny tekst Adama Smitha O sprawiedliwości i dobroczynności czy nie mniej znaną rozprawę Johna Stuarta Milla $O$ wolności, prowokując tym samym do ponownego stawiania pytań o kwestie podstawowe: czym jest wolność? kim jest człowiek? czy jest wolny? co to znaczy, że jest wolny? czy istnieje granica wolności? jeśli tak, to czy wciąż jest to wolność? co jest granicą? czy wolność jest wystarczającą kategorią, na której można by oprzeć budowę społeczeństwa? czym w kontekście wolności jest sprawiedliwość? Na ponad tysiącu stronicach znajdują się rozmaite odpowiedzi na te pytania. Żadne nie są jednak wyczerpujące, zachęcają raczej współczesnych odbiorców do pogłębienia dotychczasowych dociekań.

Pluralizm wolności, przedstawiony we wstępie antologii jako zagrożenie, okazuje się największą zaletą. Balcerowicz przywołuje teksty głównie zachodnich myślicieli, wzorując się na dziedzinowej interdyscyplinarności, co wzmacnia przekaz na gruncie polityczno-gospodarczym. Niestety autor jednego $\mathrm{z}$ tekstów wpada w

\footnotetext{
${ }^{1}$ L. Balcerowicz, Odkrywając wolność. Przeciw zniewoleniu umysłów, Warszawa 2012, s. 10.
} 
zakreśloną przez Ludwiga Wittgensteina pułapkę mylenia pojęć przyrodniczych z filozoficznymi². Mowa o artykule Michaela Gazzanigi, neurobiologa znanego przede wszystkim ze słynnych eksperymentów i badań dotyczących kalozotomii ${ }^{3}$. Nie sposób odmówić znaczenia i wartości osiągnięć tego badacza na polu nauk kognitywnych, jednakże na gruncie nauk społecznych niektóre jego teorie nie mają pełnej argumentacji, są w nich pewne niedociągnięcia ${ }^{4}$, co można zauważyć m.in. w Przyrodniczym umyśle, eseju wybranym przez Balcerowicza do antologii. Gazzaniga, wychodząc od rozważań nad teorią ewolucji i środowiskowego wpływu na jednostkę, odrzuca ten drugi czynnik na korzyść dostosowania, interpretowanego jako samokontrola jednostki i jej świadomość własnych potrzeb. Badacz krytykuje zatem interakcjonistów twierdząc, że najwięcej zyskuje człowiek, który jest pozostawiony samemu sobie. Posuwając się dalej w spekulacjach pisze: „programy pomocy [...] mogą być nie tylko nieskuteczne, lecz także wręcz szkodliwe dla osób nimi objętych”5. Próbuje tym samym wykazać negatywny wpływ interwencji państwa (tu rozwiązań socjalistycznych) na życie jego obywateli. Nie oceniając tego poglądu, a odnosząc się do zbyt luźnego związku wniosków z przesłankami, można domniemywać pewnej desperacji argumentacyjnej, jaka mogła kierować Balcerowiczem przy doborze tego tekstu. Nie sposób bowiem nie zauważyć, że zdecydowana większość tekstów zamieszczonych w antologii jest poświęcona myśli libertariańskiej, co może mierzić co bardziej konserwatywnoliberalnych czytelników. Finalnie jednak ani jedni, ani drudzy nie powinni być zawiedzeni. Ci pierwsi znajdą Konstytucję wolności Friedricha von Hayeka czy Kto wybrałby socjalizm i Dlaczego intelektualiści występujq przeciwko kapitalizmowi Roberta Nozicka (oprócz tego teksty Waltera Williamsa, Alexisa de Tocqueville'a, Miltona Friedmana); a ostatnich usatysfakcjonuje Analiza fundamentów liberalizmu Anthony'ego de Jasaya, Wolność starożytnych porównana $z$ wolnościq nowoczesna Benjamina Constanta czy Popper o demokracji: Jeszcze raz o społeczeństwie otwartym i jego wrogach Karla Poppera.

\footnotetext{
${ }^{2}$ Cf. L. Wittgenstein, Tractatus logico-philosophicus, tłum. B. Wolniewicz, Kraków 1970, s. 22.

${ }^{3}$ Zabieg przecięcia ciała modzelowatego (spoidła) łączącego ze sobą półkule mózgowe.

${ }^{4}$ Gazzaniga odrzuca społeczny i kulturowy charakter kształtowania postaw moralnych i etycznych, wskazując na ich biologiczną aprioryczność. Co więcej, twierdzi, że skoro moralność nie pochodzi od prawa, religii, wzorców kulturowych czy systemów etycznych, potrzebę jej istnienia można poddać negacji, jest bowiem zbędną nadbudową do biologii mózgu. Cf. M. Gazzaniga, The Ethical Brain, New York 2005.

${ }^{5}$ L. Balcerowicz, op. cit., s. 768.
} 
Niezwykłą trudność sprawia próba jednoznacznej oceny antologii tekstów zebranych przez Balcerowicza. Nie sposób bowiem dopatrzyć się kryterium doboru tekstów, jakim się on posłużył, poza silnie widocznym duchem libertarianizmu. W konsekwencji bardzo doskwiera brak komentarza ekonomisty do każdego zamieszczonego eseju. Z całą pewnością wzbogaciłoby to publikację.

Na korzyść antologii przemawia lekkość jej wydania (książka prezentuje się niezwykle kunsztownie jak na 1000-stronicowe tomiszcze) oraz niska cena spójna z intencją wydawniczą autora. Dla przypomnienia, było nią ożywienie debaty publicznej na temat wolności i swobód społecznych, politycznych i gospodarczych w społeczeństwach demokratycznych. Odkrywając wolność. Przeciw zniewoleniu umysłów z całym przekonaniem ten cel realizuje. Zawiera bowiem klasyczne, bogate merytorycznie teksty największych myślicieli żyjących na przestrzeni minionych kilkuset lat. Dzięki temu jest to lektura wartościowa poznawczo, atrakcyjna nie tylko dla środowisk akademickich, ale także dla aktywistów społecznych. To rzetelnie przygotowane, lecz jednak nie idealne remedium na ubożenie współczesnej debaty publicznej. Pozycja obowiązkowa dla każdego intelektualisty, zwłaszcza w kontekście znamiennej maksymy Sartre'a: „L'homme est condamné à etre libre”6.

${ }^{6}$ L'homme... - Człowiek jest skazany na wolność. (franc) 